\title{
Husserl's Project of Ultimate Elucidation and the Principle of All Principles
}

\author{
Philipp Berghofer (1) \\ Department of Philosophy, University of Graz, Graz, Austria \\ Email: philipp.berghofer@uni-graz.at
}

\begin{abstract}
:
It is well known that Husserl considered phenomenology to be First Philosophy-the ultimate science. For Husserl, this means that phenomenology must clarify the ultimate phenomenological-epistemological principle that leads to ultimate elucidation. But what is this ultimate principle and what does ultimate elucidation mean? It is the aim of this paper to answer these questions. In section 2, we shall discuss what role Husserl's principle of all principles can play in the quest for ultimate elucidation and what it means for a principle to be ultimately elucidating (letztaufklärend) and ultimately elucidated (letztaufgeklärt). We will see that the Husserlian thesis that originary presentive intuitions are an immediate and the ultimate source of justification qualifies as the ultimate epistemological principle.
\end{abstract}

Keywords: Husserl; phenomenology; epistemology; epistemic internalism; principle of all principles; ultimate elucidation

\section{Husserl's phenomenology as a subjective science of the ultimate epistemological principles}

For Husserl, the most fundamental epistemological question is how subjectivity can be the source of objective knowledge ( $c f$. Melle in Husserl 1984, xxxi). Transcendental phenomenology is supposed to provide the solution to this problem. It is a subjective science in the sense that it employs a descriptive (but also eidetic) methodology. One of its core convictions is that subjective acts are the ultimate source of all justification. In addition, Husserl's phenomenology is intended to be ultimately elucidating and ultimately elucidated. ${ }^{1}$ In this sense, Husserl understands phenomenology as the "First Philosophy," the "science of the principles, namely science of ultimate elucidation, of ultimate justification and sense-bestowing" (Husserl 1984, 165). ${ }^{2}$ This remains true for Husserl for the rest of his career although it is not always as clearly stated as in his Londoner Vorträge (1922):

Furthermore, the central significance of phenomenology within the entire sphere of sciences shall be disclosed and it shall be shown that phenomenology encompasses the whole system of sources of knowledge from which all true sciences must draw their fundamental concepts and statements and the entire force of their ultimate justification [Rechtfertigung]. Precisely for this reason, phenomenology achieves the vocation to be "First Philosophy" in the true sense, the vocation, to confer to all other sciences unity due to ultimate grounding [Begründung] and a

\footnotetext{
${ }^{1}$ In section 2, we aim at a precise characterization of ultimate elucidation. We shall see that ultimate elucidation must not be confused with infallible justification or adequate evidence.

${ }^{2}$ For similar claims, cf. Husserl 1959, 4; Husserl 1996, 330; Husserl 1999, 200, 204, 242.

(C) The Author(s) 2020. Published by Canadian Journal of Philosophy. This is an Open Access article, distributed under the terms of the Creative Commons Attribution licence (http://creativecommons.org/licenses/by/4.0/), which permits unrestricted re-use, distribution, and reproduction in any medium, provided the original work is properly cited.
} 
link to the ultimate principles and to reorganize all of these sciences as lively organs of a single, absolutely universal science, philosophy in its oldest sense. (Husserl 1999, 200; my translation)

This brings us to the question of whether phenomenology can be both a subjective science and the science of the ultimate epistemological principles. For Husserl, a science of the ultimate principles must be a subjective science. This is because in order to elucidate the ultimate epistemological principles you must show that one is justified in believing these principles. Justification, however, is gained through subjective acts: "All knowledge is realized as subjective act, and the subjective act must harbor within it what pleads and warrants its claim to legitimacy. Only in this is $<$ the justification> to be sought" (Husserl 2008, 129).

This crucial passage tells us two things: Firstly, subjective acts are the carriers of justification. Secondly, it is internal factors that give justification-conferring acts their justificatory force. The first point is the reason why phenomenology as a First Philosophy must be a study of consciousness. Since transcendental phenomenology has the ambition to elucidate the ultimate epistemological principles, phenomenology has to investigate the carriers of justification, i.e., mental states. In the next section, we shall see that, for Husserl, originary presentive intuitions are the ultimate source of justification. The second point indicates why phenomenology has to be descriptive and eidetic. Only some mental states have justificatory force. What distinguishes justification-conferring mental states from non-justification-conferring ones are internal factors. There are "immanent qualities that [...] constitute the mark of true legitimacy" (Husserl 2008, 132). Thus, Husserl is an internalist with respect to epistemic justification. Not "objective" external factors, such as truth or reliability, make experiences justifiers but factors internal to these acts. In fact, Husserl holds that it is the phenomenal character of originary givenness that gives justification-conferring experiences their justificatory force (cf. Husserl 2008, 342-43; 1982, 36).

Acts that exhibit originary givenness (i.e., originary presentive intuitions) are experiences in which the object/content is given in a presentive manner. These acts are contrasted with empty, signitive acts in which what is given to us is not the object in its actual presence but the object as something that is meant only ( $c f$. especially Husserl's Sixth Logical Investigation). The prime example of originary presentive intuitions are perceptual acts in which we are perceptually aware of the object in question. If you believe that there is a table in the room next to you, this belief is a signitive act. If you go and check and see the table, this perceptual experience is an originary presentive act. For Husserl, originary givenness and evidence are intimately related. In fact, it is the character of originary givenness that discloses the nature of evidence (for more details on Husserl's conception of evidence, $c f$. Berghofer 2019). "Evidenz is nothing but a word for the quality of givenness. [...] Evidenz is a word for the fact that [...] there is a difference between acts that not only think that something is thus and thus, but are fully certain and aware, in the manner of perspicacious seeing, of this being and being thus" (Husserl 2008, 153). It is to be noted that "originary givenness" is understood in a remarkably broad sense. Not only perceptual experiences of physical objects but also introspective intuitions of one's own mental states and eidetic (a priori) intuitions of, e.g., logical and mathematical truths are originary presentive intuitions. ${ }^{3}$ For our purpose, it is particularly significant to emphasize that also a priori intuitions of epistemological principles count as originary presentive intuitions. Importantly, "originary givenness" denotes the way an experience presents its object, which means that it characterizes the distinctive phenomenal character of an experience. ${ }^{4}$

\footnotetext{
${ }^{3}$ In his mature theory of value, Husserl insists that even value-ceptions (Wertnehmungen) are originary presentive acts (Husserl 1996, 287). To say that an experience is an originary presentive intuition means that this experience has a presentive character. However, what this means in detail depends on the type of experience. Different types of experiences correspond to different types of (originary) givenness, and different types of originary givenness correspond to different types of evidence. Very roughly, one can distinguish between inadequate (perceptual), adequate (introspective), and apodictic (eidetic) evidence.

${ }^{4}$ It is of crucial importance for Husserl to insist that while evidence or justification is subjective in the sense that an experience's justificatory force is disclosed by its phenomenal character, this does not mean that evidence is a mere feeling. Evidence is not
} 
Husserl clarifies that this phenomenal character, this form of givenness or way of an experience presenting its objects/contents, is not an external factor but an "internal, purely descriptive (or phenomenological) character" (2001a, 83). In current debates, the phenomenal character of an experience is introduced as "what it is like subjectively to undergo the experience" (Tye 2015, sec. 1). ${ }^{5}$ Importantly, an experience's phenomenal character cannot be studied "objectively" with the methods of the natural sciences but only from the first-person perspective, in a descriptive fashion. ${ }^{6}$ Thus, phenomenology must be a descriptive science. The aim, however, is to gain a priori truths about essential characteristics of different forms of originary givenness and how they relate to different forms of evidence. Hence, the descriptive methodology of Husserlian phenomenology must be supplemented by an eidetic methodology.

For Husserl, and this is a central thought that plays a crucial role in all his major works and is presumably developed in most detail in his Crisis, for any natural science subjectivity is the ultimate source of justification ( $c f$. Husserl 1984, 120). "Subjective acts motivate everything" (121). This, of course, does not mean that phenomenology can provide the laws of physics or chemistry, but the justification of any law of physics or chemistry, ultimately, depends on originary presentive acts such as visual experiences and it is the task of phenomenology to elucidate why visual experiences have justificatory force and how laws of nature can gain their justification from such experiences.

Importantly, subjectivity is not only the source of justification for the natural sciences but also for the formal sciences such as mathematics. Mathematical statements are justified by apodictic insights (Husserl 1984, 121-22) and for Husserl there is no doubt that "apodictic evidence justifies" (Husserl 1984, 122). ${ }^{7}$ Like visual experiences, however, apodictic intuitions are subjective experiences that gain their justificatory force from something internal (namely their originary presentive character). "Apodictic Evidenz, the consciousness of necessity, seen, actually experienced (and not just spurious and presumed) is, though, something subjective, a singular experience, and in it lie grounds for justification" (Husserl 2008, 120). Thus, contrary to what might be suggested in the Prolegomena, it is not a formal discipline, such as formal logic, whose task it is to elucidate the ultimate sources and principles of justification, but the task of noetics, i.e., the phenomenology of reason that is basically the study of subjective acts and modes of givenness.

It is to be noted that in this transcendental phase, apodictic insights and formal logic themselves are in need of epistemic elucidation. In the Prolegomena, Husserl pointed out that we need to accept apodictic insights because doing otherwise leads to unacceptable consequences such as relativism and skepticism (cf. Prolegomena, ch. 7). This is still true for Husserl, but now the question is a different one. The question is not, why should we believe that apodictic evidence is a source of justification? The question rather is why is apodictic evidence a source of justification? What gives it its justificatory force? Although related, these are two different questions, and Husserl realized that the latter is more fundamental.

subjective in the sense of being a mysterious index that is attached to certain judgments. Justificatory force depends only on how something is given to me, not on how I feel about what is given to me. For Husserl, to link justificatory force to feelings is "silly talk" and he insists that "the feeling and indicator theory of Evidenz is wholly meaningless" (Husserl 2008, 154).

${ }^{5}$ Christopher Erhard points out that Husserl's notion of mindedness (Zumutesein) resembles the conception of phenomenal character as it is currently used (Erhard 2014, 192; cf. particularly secs. 11, 14 of the Fifth Logical Investigation). Erhard argues that according to a Husserlian approach, every act [intentionales Erlebnis] has a phenomenal character or qualia (Erhard 2014, 192). In current debates, Elijah Chudnoff, one of the main proponents in favor of cognitive phenomenology, explicitly refers to Husserl (Chudnoff 2015, 165-66).

${ }^{6}$ As a result of the works of Thomas Nagel and Frank Jackson, the view that experiences have, in this sense, a genuinely subjective character that cannot be investigated by the natural sciences became very popular at the end of the twentieth century. Of course, in the analytic tradition, this topic remains controversial. As a side note, it should be mentioned that decades before Nagel and Jackson, physicist and Nobel laureate Erwin Schrödinger had made the same point: "The sensation of colour cannot be accounted for by the physicist's objective picture of light-waves. Could the physiologist account for it, if he had fuller knowledge than he has of the processes in the retina and the nervous processes set up by them in the optical nerve bundles and in the brain? I do not think so" (Schrödinger 1992, 154).

${ }^{7}$ For more details on Husserl's notion of apodictic evidence and his conception of a priori justification, $c f$. Berghofer 2018a. 
Here we can see the main difference between Husserl's formal and his mature transcendental logic. Formal logic is a general theory of science that abstracts from the individual sciences and aims at extracting the first principles and axioms such as the law of contradiction and the excluded middle. Based on these axioms, in further consequence, it aims at building purely logical theories (Husserl 1984, 124). A transcendental logic, on the other hand, is a descriptive and eidetic study of consciousness, subjective acts, and modes of givenness such that it can

be the ultimate science that goes back to ultimate givennesses, namely, to those givennesses that are already presupposed in all other givennesses, in all naive givennesses. That is, it wants to be the science of consciousness, the science of consciousness as pregiving in general, and specifically, the science of consciousness that pregives meant reality, and grounded upon this the ultimate elucidating science of theoretical accomplishments and of all accomplishments under the ideas of reason. (Husserl 2001b, 389-90)

Again, we are confronted with Husserl's aim of introducing transcendental phenomenology as "the ultimate elucidating science." Perhaps one of the most concise and ambitious outlines of the project of transcendental phenomenology can be found when Husserl delivers the following synopsis and prospect of a phenomenological theory of reason (noetics):

Beginning with the natural sciences, the path leads to the ontologies up to the most universal ontology (to analytics) and then on to noetics that follows all these ontologies and elucidates their principles and methods and through noetics every particular scientific knowledge is elucidated. And all knowledge, then, is transformed to absolute knowledge, to metaphysical knowledge. Thus, noetics is the theory of science in the highest sense and likewise the discipline that makes final and highest fulfillment of our desires for justification possible; because final satisfaction of knowledge can only be granted by absolute knowledge. Above all knowledge-as it belongs to its essence-being its guiding star there is the idea of the absolute. If philosophy is the title for any scientific investigation that apart from ordinary scientific work aims to serve our striving for absolute knowledge, then all logical disciplines and first and foremost noetics deserve the title philosophical discipline. (Husserl 1996, 330; my translation)

Citing this passage, Iso Kern states that "this noetics in correlation with ontology is for Husserl nothing but transcendental phenomenology" (Kern 1962, 334). Here I am in full agreement with Kern. This passage perfectly illustrates what a Husserlian transcendental phenomenology is all about.

Having said this, it should be noted that this passage can easily be misinterpreted as a claim to omniscience and infallibility. According to my understanding, a phenomenological epistemology does not aim at ensuring that we know everything or that all our justification is infallible in the sense that none of our beliefs, such as that there is a table in front of me, could turn out to be illusory. Instead, the aim of a phenomenological epistemology is ultimate elucidation (Letztaufklärung) in the sense of unfolding the ultimate sources of justification. The question is not whether my belief that there is a table is infallible (it is not). The question is whether my belief is justified, and, if so, which acts are responsible for justifying it and what it is that gives these acts their justificatory force. And most importantly: what are the fundamental epistemological principles that ultimately elucidate and are themselves ultimately elucidated?

\section{The ultimate epistemological principle and ultimate elucidation}

This section is supposed to answer two fundamental questions:

Q1: What are the ultimate epistemological principles?

Q2: What does it mean for a principle to be ultimately elucidating and ultimately elucidated, and how could one principle be both? 
For Husserl, it is clear that the ultimate principles must be epistemological principles that are a priori eidetic laws (Husserl 1984, 235-36). Husserl used a rather unambiguous terminology in order to point out that there is one principle that is more fundamental than all the others. This is his principle of all principles:

No conceivable theory can make us err with respect to the principle of all principles: that every originary presentive intuition is a legitimizing source of cognition, that everything originarily (so to speak, in its "personal" actuality) offered to us in "intuition" is to be accepted simply as what it is presented as being, but also only within the limits in which it is presented there. (Husserl 1982, 44)

Similar ideas are expressed in First Philosophy II, in which Husserl introduces his "most general principle of justification" (Husserl 1959, 32) and in the Cartesian Meditations, when he establishes his "first methodological principle" (Husserl 1960, 13). ${ }^{8}$ Let us put the basic idea of the principle of all principles as follows:

PaP: Every originary presentive intuition is a source of immediate justification.

Despite its conspicuous and promising name, $\mathrm{PaP}$ does not play the prominent role in the Ideas that one might expect and following its introduction it is hardly ever mentioned again. I believe that Husserl underestimated its full potential, and, in this section, we shall see what role it can play in the project of ultimate elucidation.

To unfold its full force, PaP must be paired with the Husserlian idea that ultimately all justification depends on originary presentive intuitions, i.e., that originary presentive intuitions are not only a source of immediate justification but also the ultimate source of justification. In Ideas $I$, this is expressed as follows:

Immediate "seeing," not merely sensuous, experiential seeing, but seeing in the universal sense as an originally presentive consciousness of any kind whatever, is the ultimate legitimizing source of all rational assertions. This source has its legitimizing function only because, and to the extent that, it is an originally presentive source. (Husserl 1982, 36)

From the context it is clear that "immediate 'seeing"' is synonymous with originary presentive intuition. Based on this passage, we can introduce the principle of ultimate justification (PUJ):

PUJ: Originary presentive intuitions are the ultimate source of justification.

Combining PaP and PUJ amounts to what I shall call the ultimate epistemological principle (UEP):

UEP: Originary presentive intuitions are an immediate and the ultimate source of justification.

In this section, we shall see that UEP can be rightfully called ultimately elucidating (letztaufklärend) and (by virtue of $\mathrm{PaP}$ ) ultimately elucidated (letztaufgeklärt). Thus, UEP is ultimately elucidating and ultimately elucidated.

In what sense can UEP be considered ultimately elucidating? Think about an arbitrary claim of physics that is more or less empirically justified by induction or inference to the best explanation.

\footnotetext{
${ }^{8}$ In these latter two principles, however, Husserl puts more focus on the claim that our judgments must not go beyond what is originarily given. In his principle of all principles, Husserl emphasizes that every originary presentive act is a source of immediate justification.
} 
In such a case, the chain of justification can be traced back to simple observations, i.e., perceptual experiences. ${ }^{9}$ Physics is in no position to elucidate why perceptual experiences are justifiers. Importantly, physicists do not need to elucidate why perceptual experiences are a source of immediate justification. Since perceptual experiences are a source of immediate justification (perceptual experiences are originary presentive acts), physicists are justified in trusting their perceptual experiences. Of course, one can pose the questions: Why are perceptual experiences justifiers? What gives them their justificatory force? These are reasonable questions which could only be answered unreasonably by empirical methods. They are questions for a First Philosophyan ultimate science that elucidates the ultimate epistemological principles. The answer, of course, is $\mathrm{PaP}$. Since every originary presentive intuition is a source of immediate justification and since perceptual experiences are originary presentive intuitions, perceptual experiences are a source of immediate justification. In this sense, UEP is ultimately elucidating. It elucidates the ultimate sources of justification by revealing the only ${ }^{10}$ sources of immediate justification (i.e., originary presentive intuitions).

Note that the physics example works analogously for mathematical insights. Without immediately justifying a priori mathematical insights, such as that 1 is smaller than 2 , no mathematical theorem could be justifiably believed. This is also true for theorems that cannot be grasped immediately but are deductively inferred. The mathematician does not need to know why such mathematical intuitions are a source of immediate justification, but every step of her proof must be accompanied by such intuitions ${ }^{11}$ and in the end it must be shown that the theorem to be proved can be traced back to self-evident statements, i.e., statements immediately justified by mathematical intuitions. Of course, it is reasonable to ask, why are mathematical intuitions such as that 1 is smaller than 2 immediately justifying? This question cannot be answered by mathematical methods. The answer, again, is that such rational intuitions are originary presentive intuitions. Thus, $\mathrm{PaP}$ is the principle that reveals why such mathematical intuitions are a source of immediate justification.

Based on the foregoing achievements, we can define that a principle is ultimately elucidating if it fulfills the following two conditions:

Ultimately Elucidating: A principle $\mathrm{P}$ is ultimately elucidating if (i) $\mathrm{P}$ demands that any justified belief gains its justification either inferentially or noninferentially from immediate justifiers and (ii) for any immediate justifier J, it is true that P elucidates why J is a source of immediate justification.

\footnotetext{
${ }^{9}$ In this spirit, Edith Stein says: "However, if we follow the chain of deliberations and conclusions that led us to this [arbitrary physical] piece of knowledge, then we will always be led back to a perception as its point of origin" (Stein 2004, 64). Of course, the Husserlian epistemology we support here amounts to a form of foundationalism that is in conflict with coherentist approaches to epistemic justification. Here three clarifications are necessary. First, Husserl's foundationalism is a moderate foundationalism that allows (i) basic beliefs to be fallible and (ii) coherence to play an important epistemic role. For more details on moderate versions of foundationalism and why Husserl should be interpreted in such a way, $c f$. Berghofer 2018b. Second, in current debates in analytic epistemology, there are prominent examples of foundationalist approaches that are similar to Husserl's moderate foundationalism (for detailed comparisons, $c f$. Berghofer 2018c; 2019). Third, Husserl's phenomenology is often interpreted as being at odds with foundationalism. I have argued elsewhere that this is because it is overlooked that moderate versions of foundationalism are possible that are significantly different from the traditional version of foundationalism advocated by Descartes (cf. Berghofer 2018b, sec. 2.4).

${ }^{10}$ It is to be noted that $\mathrm{PaP}$ on its own could not be considered ultimately elucidating. PaP only states that every originary presentive intuition is a source of immediate justification but leaves it open whether there are other sources of immediate justification and whether justification must be structured foundationally. (One might argue for the possibility of both immediate justification and justification gained by coherence alone. Only by being supplemented with PUJ does PaP become a truly foundational principle of justification.)

${ }^{11}$ Of course, a proof of a theorem $\mathrm{T}$ could be correct even if the mathematician who proves $\mathrm{T}$ does so without insight. But in this case, the mathematician would not be justified in believing her own correct proof.
} 
Since UEP fulfills both conditions of Ultimately Elucidating, it is ultimately elucidating. But is UEP itself justified?

Having clarified in which sense UEP is ultimately elucidating, let us now discuss why it is ultimately elucidated. What does it mean for a principle to be ultimately elucidated? We may say:

Ultimately Elucidated: For subject S, a principle $\mathrm{P}$ is ultimately elucidated, if (i) $\mathrm{S}$ is immediately justified in believing that $\mathrm{P}$ obtains and (ii) $\mathrm{P}$ is the principle that elucidates why $\mathrm{S}$ is immediately justified in believing that $\mathrm{P}$ obtains.

Alternatively, we may formulate Ultimately Elucidated as follows:

Ultimately Elucidated ${ }^{*}$ : A principle $\mathrm{P}$ is ultimately elucidated if by intuiting $\mathrm{P}$ you intuit the principle that elucidates why your intuiting $\mathrm{P}$ is immediately justifying.

In our case, of course, $\mathrm{P}=\mathrm{PaP}$. By intuiting $\mathrm{PaP}$, you are not only justified in believing that $\mathrm{PaP}$ obtains, but $\mathrm{PaP}$ is also the principle that elucidates why your intuiting is immediately justifying, which means that by intuiting $\mathrm{PaP}$ you are intuiting the principle (namely $\mathrm{PaP}$ ) that elucidates why your intuiting $\mathrm{PaP}$ is immediately justifying (because the act of intuiting is an originary presentive intuition and according to $\mathrm{PaP}$ every originary presentive intuition is a source of immediate justification). Let us clarify this by contrasting $\mathrm{PaP}$ with principles that do not fulfill Ultimately Elucidated.

Consider the principle that every perceptual experience is a source of immediate justification (PPE). PPE is true (since every perceptual experience is an originary presentive intuition). By intuiting PPE, you are immediately justified in believing that PPE obtains (which means that condition [i] in Ultimately Elucidated is fulfilled), but PPE is not the principle that elucidates why you are immediately justified in believing that PPE obtains (which means that condition [ii] in Ultimately Elucidated is not fulfilled). Thus, PPE is no ultimately elucidated principle. The same holds for the principle that every mathematical intuition is a source of immediate justification (PMI). PMI is true (since mathematical intuitions are originary presentive intuitions). By intuiting PMI, you are immediately justified in believing that PMI obtains (given that your intuiting is an originary presentive intuition), but PMI is not the principle that elucidates why you are immediately justified in believing that PMI obtains (because your intuiting PMI is not a mathematical intuition).

Note that when you have a perceptual experience of a laptop in front of you, this experience provides you with immediate justification for believing that there is a laptop in front of you, but this experience does not immediately justify you in believing that this experience is an immediate source of justification. An experience can only provide immediate justification with respect to what is originally presented within experience. In this case, what is originally presented is a laptop, not the content that this experience is an immediate source of justification. Originary presentive intuitions are a source of immediate justification, but they are neither ultimately elucidating nor ultimately elucidated. Such characteristics can only apply to epistemological principles, and we have seen that $\mathrm{PaP}$ is a perfect candidate for displaying these characteristics.

Here, two clarifications are appropriate. The first clarification concerns the difference between falling under a principle and knowing a principle. UEP, the basic phenomenological principle, is an internalist principle in the sense that it states that mental states, and more precisely originary presentive experiences, are our ultimate justifiers. Thus, Husserlian phenomenology is internalist in the sense of being a version of mentalism. ${ }^{12}$ This kind of internalism, however, does not imply that in order to be justified one needs to know the ultimate epistemological principles. An epistemological principle such as $\mathrm{PaP}$ is "not a principle I have to apply in order to gain knowledge; I need

\footnotetext{
${ }^{12}$ Mentalism is the view that one's justifiers consist of one's mental states. More details on mentalism are provided in the next section.
} 
only fall under it" (Van Cleve 1979, 70). Walter Hopp $(2009,11)$ discusses this in detail and concludes that Van Cleve's dictum "is just what we find phenomenologically."

When an ordinary person who has never cared about philosophy or phenomenology has a perceptual experience that presents to her a table, this person is immediately justified in believing that there is a table because this person falls under $\mathrm{PaP}$. This person does not need to know that $\mathrm{PaP}$ applies in order to be justified. This is why I have called the ultimate epistemological principle ultimately elucidating and not ultimately justifying. In deference to Van Cleve, let us call this insight rule-externalism. Importantly, rule-externalism is not inconsistent with internalism in the sense of mentalism. ${ }^{13}$ Only the phenomenologist, the person concerned with First Philosophy and ultimate elucidation, must attend to ultimate principles.

The second clarification concerns the validity and motivation of $\mathrm{PaP}$. It would be a mistake to subscribe to the following line of reasoning: If $\mathrm{PaP}$ is true, then $\mathrm{PaP}$ fulfills Ultimately Elucidated, thus we have good reason to believe that $\mathrm{PaP}$ is true. This only shows us that $\mathrm{PaP}$ is a candidate for being the ultimate epistemological principle, but it does not entail that $\mathrm{PaP}$ is true or plausible. This can be seen by realizing that a principle that is inconsistent with $\mathrm{PaP}$ could also make such a claim. Think about the following reliabilist principle:

RP: Every reliable intuition is a source of immediate justification. ${ }^{14}$

Now the reliabilist could rightfully point out that by having the reliable intuition that RP obtains (given that RP is true), you are immediately justified in believing RP (condition [i] of Ultimately Elucidated) and RP is the principle that elucidates why you are immediately justified in believing that RP obtains (condition [ii] of Ultimately Elucidated).

Of course, there are important differences between $\mathrm{PaP}$ and $\mathrm{RP}$. In the next section, I shall focus on one of them, namely the accessibility of the respective principles.

\section{The accessibility of PaP}

In current epistemological debates, it is common to distinguish between two versions of internalism: "access internalism" (or "accessibilism") and "mentalism." Accessibilism is the traditional version of internalism and demands that there must be a special kind of access to what it is that makes a belief justified.

Accessibilism: If $\mathrm{S}$ believes that $\mathrm{p}$ and some factor $\mathrm{F}$ is a justifier for $\mathrm{p}$ or plays a justificatory role in the sense of determining whether $\mathrm{S}$ is justified in believing that $\mathrm{p}$, then $\mathrm{F}$ is reflectively accessible to $\mathrm{S}$.

Accessibilism is clearly opposed to and inconsistent with reliabilism. This is because the reliability of one's belief-forming processes is usually not reflectively accessible. And if it is not reflectively accessible, it cannot play a justificatory role, contrary to what is entailed by reliabilism.

The other version of internalism, mentalism, has been introduced by Conee and Feldman (2004, 55) as a novel kind of internalism and refers to the claim that justifying factors must be internal to a person's mental life.

Mentalism: If factor $\mathrm{F}$ is a justifier, then $\mathrm{F}$ is a mental state. ${ }^{15}$

Mentalism and accessibilism are not inconsistent, but they are different claims, and, contrary to what is sometimes suggested (cf. e.g., Swinburne 2011, 196), mentalism does not entail accessibilism

\footnotetext{
${ }^{13}$ This will become clearer in the next section.

${ }^{14} \mathrm{By}$ a "reliable intuition," I understand an intuition that is formed by a reliable process.

${ }^{15}$ For a similar characterization of mentalism, $c f$. Appley and Stoutenburg 2016.
} 
(cf. Pappas 2017, sec. 6). Mentalism can avoid some well-known problems of accessibilism. For one thing, it is often objected that some animals and children clearly have justified beliefs despite the fact that they lack the sophisticated cognitive capabilities to have reflective access to their justifiers. It is plausible to assume that when a dog hears its favorite person approaching and then sees the person, the dog knows that the person is there. If it is true that dogs lack the cognitive capabilities to have reflective access to their justifiers, this is a problem for accessibilism but not for mentalism. It is not a problem for mentalism since mentalism only states that justifiers must be mental states (such as hearing a person approaching and seeing a person) without claiming that they must be reflectively accessible. Furthermore, accessibilism is often viewed as implying that if $S$ is justified in believing that $\mathrm{p}, \mathrm{S}$ must be in a position to be justified in believing that she is justified in believing that $\mathrm{p}$ ( $c f$. e.g., BonJour 1985). Such a requirement, however, is in danger of leading to a vicious regress of justification. Mentalism, however, is not committed to such a requirement.

On the other hand, accessibilism has the advantage of clearly being internalist, while this is not so clear for mentalism. Consider the following claim: only visual experiences are justifiers. Since visual experiences are mental states, this claim is clearly mentalist (and, of course, totally implausible). This claim, however, is consistent with the following claim: only reliable experiences are justifiers, and, since only visual experiences are reliable, only visual experiences are justifiers. Of course, this claim is totally implausible, but, since it is mentalist and reliabilist at the same time, this shows that mentalism is no clear commitment to internalism.

Concerning the discussion of internalism, what can we say about our principle UEP?

I1: Since UEP holds that one's ultimate justifiers are one's originary presentive intuitions, UEP is committed to some version of mentalism. ${ }^{16}$

I2: UEP is not committed to accessibilism.

I3: UEP is consistent with what we have called rule-externalism in section 2.

I4: Since Husserl supplements UEP with the claim that originary presentive intuitions gain their justificatory force precisely by virtue of their phenomenal character of originary givenness, Husserl's version of mentalism is truly internalist and incompatible with reliabilism (or externalism in general). ${ }^{17}$

I5: UEP is internally accessible in the sense that when I intuit UEP it is internally accessible to me that by intuiting UEP I intuit the principle (namely $\mathrm{PaP}$ ) that elucidates why my intuiting UEP immediately justifies me in believing that UEP obtains.

All five points are of crucial significance, but here we are primarily interested in I5. The first thing to note is that $\mathrm{I} 5$ is not inconsistent with $\mathrm{I} 2$ or I3. PaP implies that if $\mathrm{S}$ has an originary presentive intuition of $\mathrm{p}$, then $\mathrm{S}$ is (immediately) justified in believing that $\mathrm{p}$ whether or not $\mathrm{S}$ has reflective access to her justifiers and whether or not she knows that PaP obtains. But this, of course, does not rule out that $\mathrm{S}$ has reflective access to her justifiers and that she does know that $\mathrm{PaP}$ obtains. Given that $\mathrm{PaP}$ is true, the second thing to note is that I5 is very plausible. Since originary givenness denotes the phenomenal character of an experience, it is plausible to assume that to normal human beings, typically, it is accessible whether or not they have an originary presentive intuition. Thus, when I intuit $\mathrm{PaP}$, and this act of intuiting is an originary presentive intuition, then it is accessible to me that my intuiting $\mathrm{PaP}$ is an originary presentive intuition. The third thing to note is that the reliabilist principle RP discussed in the previous section does not exhibit this feature of internal accessibility. This is because reliability, in contrast to originary givenness, is no factor that is internally accessible.

\footnotetext{
${ }^{16}$ In fact, Conee and Feldman subscribe to the same version of mentalism: "We believe that all ultimate evidence is experiential evidence" (Conee and Feldman 2008, 86).

${ }^{17}$ I have argued for this claim elsewhere (cf. Berghofer 2019).
} 
Accordingly, we can formulate a stronger definition of what it means for a principle to be ultimately elucidated that satisfies the requirement for internal accessibility:

Ultimately Elucidated Internalist: For subject $\mathrm{S}$, a principle $\mathrm{P}$ is ultimately elucidated if (i) $\mathrm{S}$ is immediately justified in believing that $\mathrm{P}$ obtains, (ii) $\mathrm{P}$ is the principle that elucidates why $\mathrm{S}$ is immediately justified in believing that $\mathrm{P}$ obtains, and (iii) it is internally accessible to $\mathrm{S}$ that by intuiting $\mathrm{P}$ she intuits the principle that elucidates why her intuiting $\mathrm{P}$ immediately justifies her in believing that $\mathrm{P}$ obtains.

The reliabilist principle RP may be able to satisfy conditions (i) and (ii) but it cannot satisfy (iii). PaP satisfies all three conditions. Condition (iii) makes the ultimate principle truly self-justifying: By intuiting $\mathrm{PaP}$, you are immediately justified in believing that $\mathrm{PaP}$ obtains, you are intuiting the principle that elucidates why you are immediately justified in believing that $\mathrm{PaP}$ obtains, and by having this intuition it is internally accessible to you that by intuiting $\mathrm{PaP}$ you intuit the principle that elucidates why your intuiting $\mathrm{PaP}$ immediately justifies you in believing that $\mathrm{PaP}$ obtains. In the next section, we shall shed more light on the systematic role UEP plays within a phenomenological epistemology.

\section{The role of UEP within a phenomenological epistemology}

Although UEP is the centerpiece of a phenomenological epistemology as it is the phenomenologist's ultimately elucidating and ultimately elucidated principle, this does not mean that UEP is the finalization or even the beginning of a phenomenological epistemology. UEP tells us that originary presentive intuitions are a source of immediate justification and that they are the ultimate source of justification. However, there are further crucial phenomenological-epistemological principles. For instance, in this paper we have only touched on the question of why originary presentive intuitions are a source of justification. Husserl's genuinely phenomenological answer to this question is that they are simply by virtue of their phenomenal character of originary givenness (cf. Husserl 2008, 34243; 1982, 36). Let us call the claim that certain experiences gain their justificatory force by their distinctive, justification-conferring phenomenal character the phenomenological conception of experiential justification (PCEJ). ${ }^{18}$ The Husserlian version of PCEJ has it that this justificationconferring phenomenal character is the character of originary givenness.

Husserlian PCEJ: Certain experiences have the phenomenal character of originary givenness and if an experience $\mathrm{E}$ has the phenomenal character of originary givenness with respect to $\mathrm{p}, \mathrm{E}$, by virtue of its character of originary givenness, provides immediate prima facie justification for believing that $\mathrm{p}$.

Of course, Husserlian PCEJ and PaP are related in the sense that Husserlian PCEJ implies PaP. Arguing in favor of Husserlian PCEJ, thus, means arguing in favor of PaP. Arguing in favor of $\mathrm{PaP}$ can motivate PCEJ. Another related phenomenological principle we may dub Phenomenological Internalism:

Phenomenological Internalism: If two experiences are exactly alike phenomenologically, then they are alike justificationally, e.g., they justify the same beliefs to the same degree. ${ }^{19}$

\footnotetext{
${ }^{18}$ For a discussion, $c f$. Berghofer 2018c; 2018d.

${ }^{19}$ Reading Husserl as subscribing to Phenomenological Internalism is motivated by Husserl's statement: "Perception justifies by its phenomenological content, by its essence. Every singular perception with the same essence would justify 'the same' statement proper to it in a precisely similar way, no matter where and for whom" (Husserl 2008, 343). For a detailed discussion of this passage, $c f$. Berghofer 2018c, sec. 2.
} 
Phenomenological Internalism is neither identical to nor implied by (Husserlian) PCEJ or PaP, but of course these principles are close enough that arguing in favor of one of them can help to motivate the other ones. This is why UEP, although being the ultimately elucidating and ultimately elucidated principle, is not the finalization of a phenomenological epistemology. There are other phenomenological-epistemological principles that are not implied (but are elucidated) by UEP.

Furthermore, it would be misleading to claim that the phenomenologist can simply begin with UEP. Of course, if Husserl is right, it is not only possible to provide arguments in favor of UEP (and the other phenomenological-epistemological principles) and to motivate UEP but also to intuit UEP in the sense of having an originary presentive intuition with respect to UEP that immediately justifies believing UEP. However, such an a priori apodictic intuition, for Husserl, is an eidetic intuition and as such the product of eidetic variations. Dirk Fonfara outlines the method of eidetic variation as follows: "One begins with an experienced or imagined intuitively given object [Gegenständlichkeit] that serves as a leading example and is varied in one's imagination at will" (Husserl 2012, xix). Husserl elucidates that "[eidetic] intuition is ideative abstraction that is constituted on the basis of individual intuition. Such individual intuition, however, can be both perception and phantasy. Positings of existence are completely irrelevant" (Husserl 1987, 124). Husserl calls these individual intuitions the base (Unterlage) of eidetic intuition (cf. Husserl 1987, 126-27; cf. also Rinofner-Kreidl 2000, 135).

It is one of Husserl's core convictions (and typical for phenomenological investigations) that theories or principles should not be constructed "from above" (top down) but "from below" (bottom up) in the sense of beginning with concrete cases (cf. Husserl 1996, 326-27). ${ }^{20}$ Accordingly, if you want to disclose the nature of justification, you should begin by descriptively analyzing concrete justification-conferring experiences instead of postulating a general principle. Beginning with concrete cases can help you to "see," i.e., to have an originary presentive intuition of a general phenomenological-epistemological principle such as $\mathrm{PaP}^{21}$

\section{Conclusion}

In this paper, we have shown what it means for a principle to be ultimately elucidating and ultimately elucidated and that the phenomenological principle UEP fulfills these criteria. In section 3, we have illuminated in what sense UEP is accessible and how this distinguishes UEP from an externalist principle such as RP. We have seen that Husserl's project of ultimate elucidation is not committed to the possibility of infallible insights. Phenomenology as First Philosophy-as the ultimate science-is not a science that strives for infallibility but for ultimate elucidation as specified in section 2. In section 4, we have shed further light on the systematic role of UEP within a phenomenological epistemology and clarified how phenomenology can be a science from below although being concerned with ultimate epistemological principles.

Funding statement. This work was supported at various stages by the Austrian Academy of Sciences and by the Austrian Research Fund (FWF) (Project Number: P31758).

Philipp Berghofer is a post-doc researcher at the University of Graz. His research focus centers around phenomenology, epistemology, meta-ethics, and philosophy of physics.

\footnotetext{
${ }^{20}$ According to Husserl, it is not only true for epistemology that investigations leading to general principles must proceed bottom-up but also for ethics (cf. Husserl 1988, 414; Husserl 2004, 212).

${ }^{21}$ It is not the aim of this paper to motivate UEP or to show how discussing concrete cases can help to intuit UEP but to reveal the systematic role of UEP within a phenomenological epistemology.
} 


\section{References}

Appley, Bryan, and Stoutenburg, Gregory. (2016). “Two New Objections to Explanationism.” Synthese 194 (8): $3069-84$. https://doi.org/10.1007/s11229-016-1093-1.

Berghofer, Philipp. (2018a). “Why Husserl's Universal Empiricism Is a Moderate Rationalism.” Axiomathes 28: 539-63.

Berghofer, Philipp. (2018b). "Why Husserl Is a Moderate Foundationalist." Husserl Studies 34 (1): 1-23.

Berghofer, Philipp. (2018c). "Husserl's Conception of Experiential Justification: What It Is and Why It Matters." Husserl Studies 34 (2): 145-70.

Berghofer, Philipp. (2018d). “Towards a Phenomenological Conception of Experiential Justification.” Synthese. https://doi. org/10.1007/s11229-018-1744-5.

Berghofer, Philipp. (2019). “On the Nature and Systematic Role of Evidence: Husserl as a Proponent of Mentalist Evidentialism?" European Journal of Philosophy 27 (1): 98-117.

BonJour, Laurence. (1985). The Structure of Empirical Knowledge. Cambridge, MA: Harvard University Press.

Chudnoff, Elijah. (2015). Cognitive Phenomenology. New York: Routledge.

Conee, Earl, and Feldman, Richard. (2008). “Evidence.” In Epistemology: New Essays, edited by Quentin Smith, 83-104. Oxford: Oxford University Press.

Conee, Earl and Feldman, Richard. (2004). Evidentialism, Oxford: Oxford University Press.

Erhard, Christopher. (2014). Denken über nichts - Intentionalität und Nicht-Existenz bei Husserl. Berlin: De Gruyter.

Hopp, Walter. (2009). "Phenomenology and Fallibility.” Husserl Studies 25: 1-14.

Husserl, Edmund. (2012). Zur Lehre vom Wesen und zur Methode der eidetischen Variation. Texte aus dem Nachlass (1891-1935). Husserliana XLI. New York: Springer.

Husserl, Edmund. (2008). Introduction to Logic and Theory of Knowledge: Lectures 1906/07. Translated by Claire Ortiz Hill. Dordrecht, Ger.: Springer.

Husserl, Edmund. (2004). Einleitung in die Ethik. Vorlesungen Sommersemester 1920 und 1924. Husserliana XXXVII. Dordrecht, Ger.: Kluwer Academic Publishers.

Husserl, Edmund. (2001a). Logical Investigations Vol. 2. Translated by J. N. Findlay. London: Routledge.

Husserl, Edmund. (2001b). Analyses Concerning Active and Passive Synthesis. Translated by Anthony Steinbock. Dordrecht, Ger.: Kluwer Academic Publishers.

Husserl, Edmund. (1999). “Londoner Vorträge 1922.” Husserl Studies 16: 183-254.

Husserl, Edmund. (1996). Logik und allgemeine Wissenschaftstheorie. Husserliana XXX. Dordrecht, Ger.: Kluwer Academic Publishers.

Husserl, Edmund. (1988). Vorlesung über Ethik und Wertlehre (1908-1914). Husserliana XXVIII. Dordrecht, Ger.: Kluwer Academic Publishers.

Husserl, Edmund. (1987). Vorlesungen über Bedeutungslehre. Sommersemeseter 1908. Husserliana XXVI. Dordrecht, Ger.: Martinus Nijhoff.

Husserl, Edmund. (1984). Einleitung in die Logik und Erkenntnistheorie. Vorlesungen 1906/07. Husserliana XXIV. Dordrecht, Ger.: Nijhoff.

Husserl, Edmund. (1982). Ideas Pertaining to a Pure Phenomenology and to a Phenomenological Philosophy First book. Translated by Fred Kersten. The Hague: Martinus Nijhoff.

Husserl, Edmund. (1960). Cartesian Meditations. Translated by Dorion Cairns. The Hague: Martinus Nijhoff.

Husserl, Edmund. (1959). Erste Philosophie (1923/24). Zweiter Teil. Husserliana VIII. The Hague: Martinus Nijhoff.

Kern, Iso. (1962). "Die drei Wege zur transzendental-phaenomenologischen Reduktion in der Philosophie Edmund Husserls." Tijdschrift voor Filosofie 24 (2): 303-49.

Pappas, George. (2017). “Internalist vs. Externalist Conceptions of Epistemic Justification.” The Stanford Encyclopedia of Philosophy, Fall 2017. Edited by Edward N. Zalta. https://plato.stanford.edu/archives/fall2017/entries/justep-intext.

Rinofner-Kreidl, Sonja. (2000). Edmund Husserl: Zeitlichkeit und Intentionalität. Freiburg/München, Ger.: Verlag Karl Alber. Schrödinger, Erwin. (1992). What Is Life? Cambridge, MA: Cambridge University Press.

Stein, Edith. (2004). Einführung in die Philosophie. Edith Stein Gesamtausgabe Band 8. Freiburg, Ger.: Herder.

Swinburne, Richard. (2011). "Evidence." In Evidentialism and Its Discontents, edited by Trent Dougherty, 195-206. Oxford: Oxford University Press.

Tye, Michael. (2015). “Qualia.” The Stanford Encyclopedia of Philosophy. Fall 2015 Edition. Edited by Edward N. Zalta. http:// plato.stanford.edu/archives/fall2015/entries/qualia.

Van Cleve, James. (1979). “Foundationalism, Epistemic Principles, and the Cartesian Circle.” The Philosophical Review 88 (1): 55-91.

Cite this article: Berghofer, P. 2020. Husserl's Project of Ultimate Elucidation and the Principle of All Principles. Canadian Journal of Philosophy 50: 285-296, doi:10.1017/can.2019.40 